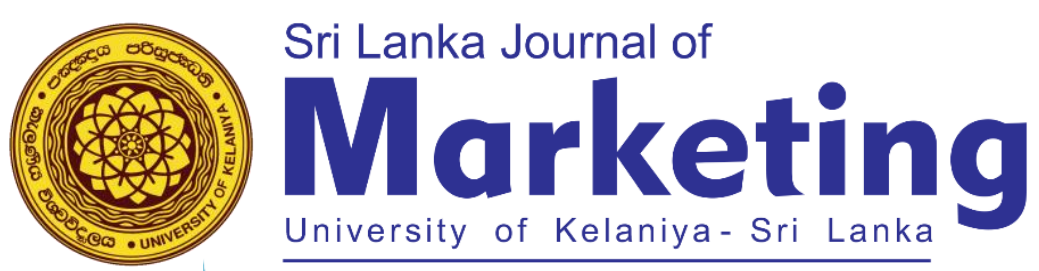

\title{
The Millennials as Stayers versus Switchers: The Context of Mobile Phone Services in Sri Lanka
}

\author{
Karunaratna A.C. \\ Senior Lecturer, University of Ruhuna, Matara, Sri Lanka \\ acruhuna@gmail.com
}

\begin{abstract}
The study was conducted to evaluate the nature of the behavioral aspects of the Millennials in terms of loyal and switching behavior as reference to the mobile phone services subscription. The study was conducted in two stages. At the initial stage, a customer survey was conducted with a sample of 521 respondents to identify the nature of retention and switching behaviour of the Millennials in the context of mobile phone services. The comprehensive analysis of customer responses extended the study to the second stage which involved in focus group discussions to probe the perceptions towards the decision of remaining loyal or switching and identify the nature and characteristics of each type of customer. Accordingly, the triangulation research approach involving both qualitative and quantitative data collection methods was adopted to achieve the desired objectives of the study. The study is significant as it evaluates the nature of the behaviour of the Millennials in the context of remaining versus switching and presents a semantic profile of customers with four types of loyalty namely fanatic, satisfied, brand loyal and captive and four types of switchers namely convenience seeker, discontented customer, variety seeker and price-conscious customer with respect to the mobile phone services industry.
\end{abstract}

Keywords: Loyal, Millennials, Retention, Switching 


\section{INTRODUCTION}

Customer retention is one of the key strategies in marketing since the acquisition of new customers has become far more expensive than keeping existing customers. (Reichheld \& Kenny, 1990; Zeithaml, Berry \& Parasuraman, 1996; Reichheld \& Schefter, 2000; Skogland \& Siguaw, 2004; Ang \& Buttle, 2006; Kotler \& Keller, 2012). Accordingly, the focus of marketing from customer acquisition to customer retention has accentuated due to product proliferation and severe competition in the contemporary business context (Moreira, Silva \& Moutinho, 2016). Meanwhile, Ahn, Han and Lee (2006) state that a company, in order to be successful, the strategic focus ought to shift from acquiring customers to retaining customers by reducing customer churn. Accordingly, the concept of customer loyalty has drawn a renewed interest in the current marketing context in formulating strategies for customer retention (Watson et al., 2015; Nyadzayo \& Khajehzadeh, 2016; Jung, Han, \& Oh, 2017). Although customer retention is an essential goal, customer defection rate is also very high in the competitive business domain, especially in the services context (Lemmens \& Gupta, 2020). Many companies, especially retail firms and service organizations face a huge challenge in retaining customers due to higher rate of customer defection commonly known as customer switching (Bitner, 1990; Keaveney, 1995; Patterson \& Smith, 2003; Pirc, 2006; Wieringa \& Verhoef, 2007; Vyas \& Raitani, 2014; Jung et al., 2017).

Customer loyalty is treated as the focal point of interest for marketing researchers and practitioners (Russell-Bennett, McColl-Kennedy \& Coote, 2007) and has largely recognized as the new mantra for sustained growth and profitability (Reichheld et al., 2000; Rai \& Srivastava, 2012). The concept of customer loyalty has thus paid a higher interest in the contemporary business context because customer loyalty is treated as one of the best measures of the success of an organization (Nyadzayo \& Khajehzadeh, 2016). Winning customer loyalty has become a huge challenge, since customer switching has significantly increased in the current competitive business context where savvy customers enjoy brand proliferation in mature markets. The loyal customer is treated as an asset of a company. Kandampully and Suhartanto (2000) identify loyal customer as the customer who purchases from the same service provider whenever possible, and who continues to recommend or maintains a positive attitude towards the service provider.

The mobile phone today is not merely a device used for just communication, but it is a mini-computer and has been expanded its depth and breadth of services adding various attributes and features by service providers which has made a revolution in human life and changed the entire behaviour of consumers creating a new fashion of life. This happened due to the rapid development of digital technology. There is no argument that the mobile phone has become the most powerful tool in the life of the Millennials to the date which strengthens the relationships and social bonds. The Millennials are treated as the first high-tech generation (Norum, 2003) and digital natives who have grown up with mobile phones, 
computers and other collaboration techniques (McMahon \& Pospisil, 2005; Bess \& Bartolini, 2011; McMahon \& Jung, 2011). The Millennials have been exposed to technology from an early age (JonasDwyer \& Pospisil, 2004). Moreover, the millennial consumers are treated as an important category as early adopters of new technology and for their powerful aggregate spending and heavy usage of mobile devices and services (Hahn \& Kim, 2016). Studying the nature of consumer behaviour and identifying their demographic and psychographic characteristics have become critical in applying customer retention strategies. Accordingly, various classifications of customers based on their level of loyalty and switching behaviour have been introduced by various scholars and this exercise has made easier for the marketers to employ suitable marketing strategies for each type of customer groups (Aaker, 1991; Knox \& Walker, 2001; Rossiter \& Bellman, 2005; Rowley, 2005). However, the lack of adequate classification of the Millennials led the researcher to evaluate the nature of customer loyalty and switching in referring to the mobile phone services industry as an essential as well as intimate tool of the Millennials. Moreover, the studies in relation to the behaviour of loyalty and switching of Millennials are scarce in the marketing literature and a few studies conducted on this issue also affirm that the loyalty behaviour of Millennials is rather complex (Reisenwitz \& Iyer, 2009; Lodes \& Buff, 2009; Gurau, 2012). Therefore, the mobile phone services industry was selected to analyse the loyal versus switching behaviour of the Millennials.

\section{LITERATURE REVIEW:}

\subsection{The Millennials:}

The Millennials are recognized as the generation who were born between 1980 and 2000, commonly known as Generation Y (Gurau, 2012), named as various terms such as Internet Generation, Echo Boomers, the Boomlet, Nexters, the Nintendo Generation, the Digital Generation etc. (Raines, 2002). The Millennial generation possesses different values, characteristics and behaviour compared to previous generations (Gurau, 2012). The main characteristics of the Millennials are recognized as sociable, optimistic, talented, well-educated, collaborative, open-minded, influential, and achievementoriented (Raines, 2002). According to Young and Hinesly (2012), the profile of Millennials includes confident and self-reliant; technologically savvy and connected; open to change and diversity; closely connected to family and social organizations; service oriented; effective at multitasking and expectant of immediate access to information. And also, this is treated as the most educated, well-travelled and technologically sophisticated generation (Crampton \& Hodge, 2009). Meanwhile, Hahn and Kim (2016) identify Millennials as the crucial market segment in mobile marketing and retail industry due to their heavy usage and higher dependency on mobile devices. The Millennials have been exposed to technology from an early age (Jonas-Dwyer \& Pospisil, 2004) and hence treated as the first high-tech generation that have grown up with mobile phones and computers (Norum, 2003; Bess \& Bartolini, 2011; McMahon \& Jung, 2011). Accordingly, millennial consumers are an important category as early 
adopters of new technology and for their powerful aggregate spending and heavy usage of mobile devices and services (Hahn \& Kim, 2016). Two elements that are unique to the millennial generation relate to mobile technology and social network connectivity (Eastman et al., 2014). The Millennials are fascinated with new technologies (Richards, 2011). At current, there are many tools enjoyed by the Millennials over previous generations, and one of the major tools among them is the mobile phone. One of the key features of Millennials is identified as connected 24/7 where many prefer chatting on line talking on the phone (Raines, 2002). According to Machavolu and Narayana (2016), the Millennials come up with unprecedented shopping habits and preferences where most of the millennials own a smartphone or two which has disrupted the shopping trends in the market and smartphones have penetrated deep into their personal lives. Moreover, smart millennials welcome experiments in product delivery and payment methods, spurring online shopping trend (Machavolu \& Narayana, 2016). There are conflicting theories in relation to the brand loyalty of Millennials where some customers demonstrate a high level of loyalty while some are less loyal (Reisenwitz \& Iyer, 2009; Lodes \& Buff, 2009; Gurau, 2012). Meanwhile, Gurau (2012) stress the need for more research especially for a change of paradigm as conflicting evidence exists regarding the attitudes and behaviour of Millennials towards brands.

\subsection{Classifications of Customers:}

Customers are treated as a valuable asset for a company where managing customers is really important for the success of business activities. Accordingly, customers can be acquired, retained and grown in value over time (Ang \& Buttle, 2006). Marketers who produce goods and services for satisfying customer needs recognize that they are unable to serve all consumers in a particular market in the same way. Instead, they are willing to segment customers by using different variables such as demographic, geographic, psychographic and behavioural (Kotler \& Keller, 2012), and consumer-rooted and consumption-specific variables (Schiffman, Wisenblit \& Kumar, 2015). Then, they target customer group or groups to the greater extent that they can serve best and, accordingly develop suitable marketing strategies to fulfil customer requirements. Classification of customers and profiling them with specific attributes will help marketers to formulate and apply suitable marketing strategies for each type of customer group in this regard. Behavioural segmentation variables such as user status and loyalty status are heavily used in classifying and profiling customers (Reinartz \& Kumar, 2002; Rossiter $\&$ Bellman, 2005). Therefore, scholars have tended to classify customers based on their level of loyalty exhibited and switching intention in order to to target and serve in respective markets (Aaker, 1991; Knox \& Walker, 2001; Rossiter \& Bellman, 2005; Rowley, 2005). Moreover, marketers are interested in identifying the behaviour of customers in terms of attitudinal and behavioural components since those components determine the decision on retention versus defection. Thus, scholars have evaluated these 
attitudinal and behavioural measures of customers (Dick \& Basu, 1994; Jones \& Sasser, 1995; Reinartz \& Kumar, 2002; Rossiter \& Bellman, 2005; Watson et al., 2015; Khajeheian \& Ebrahimi, 2020).

Aaker (1991) has presented a brand loyalty pyramid including five levels of brand loyalty ranging from not loyal to very loyal. Accordingly, switchers identified as price sensitive can be treated as customers who usually switch their brands exhibiting no loyalty to any particular brand. Satisfied or habitual buyer can be recognized as reasonably satisfied buyer. They have adopted to purchase a particular brand as a habit. Satisfied buyer with switching costs is the type of buyer who is reluctant to switch to a competing brand due to existing thresholds (switching costs). Brand likers are typified as true brand enthusiasts whose brand preference is mostly engendered by an experience of emotional and rational benefits. Committed buyer who represents the highest level of the brand pyramid is closely tied with the brand. Meanwhile, Rossiter and Bellman (2005) categorize the consumers into five groups based on their purchasing behaviour such as brand loyalty, favorable brand switchers, other-brand switchers, otherbrand loyals and new-category users. The first two categories can be identified as customers that are loyal to a specific brand. The category referred as 'brand loyal' would be customers who are loyal to a single brand or a few brands, which is called multi brand loyals. The second category of customers who play as 'favourable brand switchers' purchase and have a preference for a specific brand, but at the same time they have interest to try competing brands as well. The third and the fourth categories contain customers of other brands that could possibly be tempted to switch to an alternative brand. The third category called 'other brand switchers' are treated as customers without a preference for any specific brand. However, the 'other brand loyals' are customers who are loyal at least to one other brand. The customers who represent the final category do not use any specific product brand; hence do not exhibit any loyalty. Meantime, Rowley (2005) has proposed the four 'Cs' of customer loyalty including four types of customers such as captive, convenience-seekers, contended and committed based on customer loyalty. Table 01 presents a review of the classification of customers in terms of retention, loyalty and switching behaviour as identified by different scholars and practitioners.

Table 1: Classification of Customers: A Review

\begin{tabular}{|l|l|}
\hline \multicolumn{1}{|c|}{ Author/s } & \multicolumn{1}{c|}{ Types of Customers } \\
\hline Brown (1953) & Hard-core Loyals, Split Loyals, Shifting Loyals, Switchers \\
\hline Aaker (1991) & $\begin{array}{l}\text { Switchers, Satisfied or Habitual Buyers, Satisfied Buyer with } \\
\text { Switching Costs, Brand Likers, Committed Buyer }\end{array}$ \\
\hline Jones \& Sasser (1995) & Loyalist, Apostle, Defector, Terrorist, Mercenary, Hostage \\
\hline Knox \& Walker (2001) & Loyals, Habituals, Variety Seekers, Switchers \\
\hline Curasi \& Kennedy (2002) & $\begin{array}{l}\text { Prisoners, Detached Loyalists, Purchased Loyalists, Satisfied } \\
\text { Loyalists, Apostles }\end{array}$ \\
\hline
\end{tabular}




\begin{tabular}{|l|l|}
\hline Reinartz \& Kumar (2002) & Butterflies, True Friends, Strangers, Barnacles \\
\hline Rossiter \& Bellman (2005) & $\begin{array}{l}\text { Brand loyals, Favourable brand switchers, Other-brand } \\
\text { switchers, Other-brand loyals, New-category users }\end{array}$ \\
\hline Rowley (2005) & Captive, Convenience-seekers, Contended, Committed \\
\hline Moreira et al. (2016) & Stayers, Switchers, Heavy Switchers \\
\hline
\end{tabular}

\subsection{Customer Loyalty:}

The concept of customer loyalty is of major interest in the contemporary business context, which is treated as one of the best measures of the success of an organization (Nyadzayo \& Khajehzadeh, 2016). Singh and Sirdeshmukh (2000) express consumer loyalty is emerging as the marketplace currency for the twenty-first century. Meanwhile, Chen (2012) identifies customer loyalty as an essential element in business survival and development and regarded as a competitive asset for an organization. While achieving customer loyalty is a primary marketing goal for any company, building loyalty and reaping its rewards has become a huge challenge (Watson et al., 2015). Strategic move on customer loyalty has drawn a higher interest in the competitive business context, where creating and maintaining customer loyalty has become a strategic mandate (Ganesh, Arnold \& Reynolds, 2000). It is apparent that the success of a firm largely depends on its capability, not only to attract consumers, but also retain them in long run (Mellens, Dekimpe \& Steenkamp, 1996; Roos, 1999).

Loyalty is defined as repeated purchases of particular product or service during a certain period of time (Yi \& Jeon, 2003). Meanwhile, Oliver (1999, p. 34) defines loyalty as "deeply held commitment to rebuy or repatronize a preferred product/services consistently in the future, thereby causing repetitive same-brand or same brand-set purchasing, despite situational influences and marketing efforts having the potential to cause switching behaviour". According to Mellens et al. (1996) brand loyalty implies consistent repurchase of a brand, resulting from a positive affection of the consumer towards that brand. According to Andreassen and Lindestad (1998), customer loyalty means an intended behaviour towards the services or the company and this includes the likelihood of future renewal of services contracts or the profitability of a change in patronage, how likely the customer is to provide positive word of mouth, or the likelihood of customers providing voice. When paying attention on the various definitions of customer loyalty, it could be noted that many marketers attempt to enhance customer loyalty since it is the key for winning the customers hearts and minds. Meanwhile, Watson et al. (2015) accentuate that although achieving customer loyalty is a primary marketing goals, building loyalty and reaping its rewards remain on-going challenges. Customer satisfaction is the most essential element which has a huge impact on loyalty (Jones \& Sasser, 1995; Oliver, 1999; Chen, 2012; Kasiri et al., 2017; Voon, 2017; Han et al., 2018). Enhancing the level of customer loyalty through satisfying customer needs has become imperative for customer retention since highly satisfied customer stays loyal longer, talks 
favourably about the company products and services, pay less attention on competing brands, and especially less sensitive to price and offers of competing brands (Aaker, 1991; Bowen \& Shoemaker, 1998; Reichheld et al., 2000; Skogland \& Siguaw, 2004; Kotler \& Keller, 2012; Vuuren, RobertsLombard, \& Tonder, 2012).

\subsection{Customer Retention:}

Customer retention presents a significant challenge for many service companies in today's turbulent business environment (Ascarza et al., 2017). According to Reichheld (2003), the best companies focus on customer retention rates which provide a valuable link to profitability. Consequently, strategic move on customer retention has drawn a higher interest in the contemporary marketing context since customer attraction has become a huge challenge (Reichheld \& Kenny, 1990; Zeithaml et al., 1996; Reichheld \& Schefter, 2000; Skogland \& Siguaw, 2004; Ang \& Buttle, 2006; Kotler \& Keller, 2012). Accordingly, customer retention is recognized as a key to achieving long-term business success (Gul et al., 2018). Reichheld et al., (2000) state that the highest retention rate as the evidence of superior customer value earns the best profits in the most of industries. However, customer retention has become a challenging task. It is essential to identify the target customers' needs and wants accurately and satisfy them over competitors to retain them in long run. Therefore, the trend in marketing towards building relationships with customers continues to grow, and marketers have become increasingly interested in retaining customers over long-run (Lemon, White \& Winer, 2002). Accordingly, many companies that compete in this dynamic business setting have realized customer loyalty as an effective tool for customer retention. According to Peighambari (2007), it is becoming an industry-wide belief that the best core marketing strategy for the future is to try to retain existing customers through customer loyalty. Perceptions on individual-level behavioural intentions can be viewed as signals of retention or defection (Zeithaml et al., 1996). Shaaban and Hassanien (2016) recognize customer retention as the action that a service provider undertakes in order to reduce customer dissatisfaction and decrease the profitability of leaving a service provider. According to Seo et al. (2008), a strong relationship exists between switching costs and customer retention behaviour in the mobile telecommunications service market. Moreover, Peighambari (2007) also reveals that switching barriers have a positive significant influence on customer retention in the context of Iranian telecommunication services. Oyeniyi and Abiodun (2010) state that switching barriers affect significantly on the level of customer retention, and also influence on the relationship between customer satisfaction and customer retention indicating switching costs to be used when predicting consumer behaviour in the mobile telecommunications sector. As Peighambari (2007) stressed it has to be predicted a more competitive market in coming years where the players have to set their retention targets from now. When the number of subscribers reaches its saturation point, creating and securing new customers is not only difficult but also costly in terms of marketing in the context of mobile telecommunications services. 


\subsection{Customer Defection:}

Customer switching behaviour has become an interesting phenomenon among scholars (Bitner, 1990; Keaveney, 1995; Bansal \& Taylor, 1999; Lee, Lee \& Feick, 2001; Patterson \& Smith, 2003; Pirc, 2006; Oyeniyi \& Abiodun, 2010; Chuang \& Tai, 2016; Jung et al., 2017). The term customer switching is interchangeably used to refer customer defection since both terms are used to refer the same phenomenon (Ahn et al., 2006). Therefore, this study will use both terms in citing the sources as indicated by each scholar, where applicable. Pirc (2006) admits that understanding customer propensity to react to competitors' marketing actions to switch can provide valuable insight into the study of determinants of relationship maintenance and customer loyalty. According to Bitner (1990), the key switching factors are time or money constraints, lack of alternatives, switching costs and habit that cause customer loyalty due to lack of ability to switch. Patterson and Smith (2003) have identified six potential switching barriers such as search costs, loss of social bonds, setup costs, functional risk, attractiveness of alternatives and loss of special treatment benefits. Keaveney (1995) explored eight major factors such as core service failures, service encounter failures, pricing, inconvenience, employee responses to service failures, attraction by competitors, ethical problems and involuntary switching which cause customer switching in the services industry.

Switching barriers as the form of switching costs is one of the popularly addressed phenomena in evaluating loyal behaviour of customers (Lee et al., 2001; Eshghi et al., 2007; Deng et al., 2009). Switching costs play a major role to discouragee customers' switching decision. Switching cost is conceptualized as the perception of the magnitude of the additional costs required to terminate a relationship and secure an alternative one (Patterson \& Smith, 2003). Switching costs are treated as "costs that are incurred by consumers for terminating transaction relationships and initiating a new relation" (Oyeniyi \& Abiodun, 2010, p. 112). According to Lee et al. (2001), switching costs are costs that the consumer incurs by changing providers that they would not incur if they stayed with their current provider. Whenever consumers switch service providers, they incur different types of costs such as psychological, emotional, search effort (time), and even economic. According to Oyeniyi and Abiodun (2010), a number of critical costs have to be considered i.e. costs of informing others, costs of acquiring new services package or connection, costs associated with breaking long-standing relationship with the services provider, and costs of searching and dealing with new services provider. Burnham, Frels and Mahajan (2003) present eight distinct switching cost facets such as economic risk costs, evaluation costs, learning costs, setup costs, benefits loss costs, monetary loss costs, personal relationship loss costs and brand relationship loss costs. While Andreassen and Lanseng (1997) state that customers may be loyal due to high switching barriers or lack of real alternatives, Aydin, Ozer and Arasil (2005) confirm that switching cost directly affects customer loyalty. Eshghi et al., (2007), investigating the determinants of propensity to switch of wireless service providers, report that wireless 
telephone customers in the United States had faced significant costs in switching from one wireless service provider to another, because doing so would have meant the loss of a phone number known by friends, relatives and business associates. As a result, a vast majority of customers have tended to stay with their wireless service provider regardless of their satisfaction with the service. Ahn et al., (2006) declare that managing customer churn is of great concern among the telecommunications service companies where call quality-related factors mostly influence customer churn in the mobile telecommunications service industry.

\section{METHODOLOGY:}

The study was conducted to evaluate the nature of the behavioural aspects of the Millennials in terms of loyal and switching behaviour referring to the mobile phone services industry. The triangulation approach, involving both qualitative and quantitative data collection methods, was adopted to achieve the desired objectives of the study. The qualitative descriptive research approach was adopted to conduct the study as the qualitative description is considered as a valuable research method of choice when straight descriptions of phenomena are desired (Sandelowski, 2000). Qualitative descriptive studies are especially useful when getting into know who does, what and where of events are taken place (Sandelowski, 2000). The study was conducted in two stages. At the initial stage, a customer survey was carried out with a sample of 521 respondents including 302 male and 219 female undergraduates as depicted in table 02. University undergraduates who were born between 1994 - 1998 were selected as the unit of analysis of the study as they cover both aspects, the Millennials cohort and the heavy users of the mobile phone services. Since the undergraduates were used as the sample of the study, the age of the respondents represents the early twenties ranging from 22 to 24 years.

Table 02: The Profile of the Sample

\begin{tabular}{|c|c|c|}
\hline & Frequency & Percentage \\
\hline \multicolumn{3}{|l|}{ Gender } \\
\hline Male & 302 & $58 \%$ \\
\hline Female & 219 & $42 \%$ \\
\hline \multicolumn{3}{|l|}{ Usage Duration } \\
\hline Below 02 & 38 & $7 \%$ \\
\hline $02-04$ Years & 177 & $34 \%$ \\
\hline $05-06$ Years & 280 & $54 \%$ \\
\hline 07 and Above & 26 & $5 \%$ \\
\hline \multicolumn{3}{|c|}{ Number of Switching } \\
\hline Non Switching & 52 & $10 \%$ \\
\hline Within Brand & 62 & $12 \%$ \\
\hline Between Brand & & \\
\hline
\end{tabular}




\begin{tabular}{|c|c|c|}
\hline 1 & 355 & $68 \%$ \\
\hline 2 & 43 & $8 \%$ \\
\hline 3 & 9 & $2 \%$ \\
\hline Total & 521 & $100 \%$ \\
\hline
\end{tabular}

The first phase of the study was conducted to identify the nature of retention versus defection behaviour. The respondents were asked to mention the nearest switching decision, including the previous brand/package and the current brand/package, and were further advised to mention the most influential factor (factors) that had affected their switching decision. Table 02 shows that the usage duration of mobile phone services of the respondents is not much longer due to their age level. According to the table, only $5 \%$ of the sample has used mobile phone over 6 years while the rest of the sample, for instance $95 \%$, have used mobile phone six years or less. Moreover, 280 respondents ( $54 \%$ of the sample) have been using mobile phone for 5 to 6 years while 2 - 4 years' category represents 177 respondents (34\%). As far as the switching behaviour of mobile phone service subscription is concerned, 355 respondents $(68 \%)$ have switched only once in their life. In addition, 43 respondents have switched twice and 9 respondents have switched thrice. Moreover, 62 subscribers have switched within the same brand from prepaid to postpaid vice versa. Due to this nature of switching behaviour within a shorter time period and high memory capacity as the youth, the telescoping error and squishing error were not affected on the decisions and views of the respondents. Meantime, those who retained were also advised to mention the most influential factor (factors) for their retention decision.

Next, the factors affected mobile subscribers' decisions on defection versus retention were separately evaluated and those influential factors of each respondent were tabulated and a summary of those factors is shown in table 04 under the section of the results and discussion. As a result of the analysis of the factors for the retention and defection intention of the Millennials, four types of loyal customers and four types of switchers were recognized in referring to the types of customers as reviewed in table 01 . Accordingly, in the second stage, separate focus group discussions were held with randomly selected members of all eight groups of the millennial customers to probe the perceptions towards their decision to remain or switch. For this purpose, 168 subscribers were selected from the sample. Accordingly, 26 subscribers identified as 'Fanatic', 22 subscribers identified as 'Satisfied', 14 subscribers identified as 'Captive', and 22 out of 52 'Brand Loyal' subscribers were selected. Further, 21 subscribers from each switching category were randomly selected from the existing sample with a total of 84 subscribers to match with loyal categories. These eight categories of customers were produced based on their most influential factor of defection versus retention in referring to the types of customers as introduced by various scholars. The respondents were encouraged to reveal their inner feelings and perceptions regarding their behaviour. Accordingly, the specific questions in relation to their behaviour were addressed. For instance, some of them are as follows. What specific motive persuaded you to retain 
(switch) the brand/package? Will you intend to continue this subscription in future or switch to another brand? Why do you select this brand as your most preferred choice among competitive brands? Will you contribute to recommend this brand and its benefits to others? Based on the responses, the profile of each of the millennial customer group was developed and, the nature of behaviour in terms of attitudinal and behavioural components was also evaluated.

\section{DATA ANALYSIS:}

The analysis was mainly conducted in referring to the nature of behaviour of mobile phone service subscription by the Millennials. It was interesting to evaluate how the Millennials as mobile phone subscribers switched among different brands and packages while others remained. This study provides a new perspective in analyzing the behaviour of customers using a contingency table as an analytical tool. Accordingly, table 03 illustrates the nature of switching and retention of mobile phone subscribers. For the ethical purpose, the exact brand names are not used and the brands will be named from Brand A to Brand E.

According to table 03, only 138 subscribers have used Brand A before switching among the brands. At current, the total subscription to Brand A is 180 . While 10 prepaid subscribers (who were later identified as 'Fanatic') remained without changing either brand or package, 30 Brand A subscribers (identified as 'Brand Loyal') have changed their package either from prepaid to post-paid or post-paid to prepaid without changing the brand. Totally, 98 subscribers, for instance; 35 to Brand B, 18 to Brand C, 12 to Brand D and 33 to Brand E, have switched.

Meantime, 71 Brand B subscribers, 32 Brand C subscribers, 19 Brand D subscribers, and 18 Brand E subscribers have shifted to Brand A. Most of these subscribers were attracted by Brand A due to the lower rates of Brand A when compared to other brands. The discussions held with customers revealed that they have mainly switched to Brand A with the intention of enjoying low-rate as directed by their price-conscious mentality. As such, that particular customer group was classified as 'Price-conscious' customers. It was reported that 140 mobile subscribers being price sensitive had changed their package for the purpose of enjoying lower rates. As a whole, 98 mobile phone subscribers of Brand A have switched to other brands while 140 mobile phone subscribers have switched to Brand A.

Currently, Brand B consists of 140 subscribers in the sample where it was revealed that 176 subscribers enjoyed the service of this brand previously. It was reported that 16 subscribers (who were later identified and named as Fanatics) remained with the existing brand as their first package while another 32 Brand B subscribers have changed only the package sticking with the Brand B itself. Meanwhile, 35 Brand A subscribers have shifted to Brand B. Further, 20 Brand C subscribers, 25 Brand D subscribers and 12 Brand E subscribers have shifted to Brand B. Meantime, Brand B reports the highest number of 
switches to other brands. For instance, 71 subscribers to Brand A, 12 subscribers to Brand C, 15 subscribers to Brand D and 30 subscribers to Brand $\mathrm{E}$ have switched with reporting the total switches 128 from Brand B. Meantime, it was reported 124 total switches to Brand B from the other brands.

Table 03: The Nature of Subscribers' Switching Behaviour and Retention among Service Providers

\begin{tabular}{|c|c|c|c|c|c|c|c|}
\hline & & \multicolumn{6}{|c|}{ Switched to } \\
\hline & Brand & Brand $A$ & Brand $B$ & Brand $C$ & Brand $D$ & Brand $E$ & Pre-subscription \\
\hline $\begin{array}{l}\mathrm{S} \\
\mathrm{w}\end{array}$ & Brand $A$ & $30(10)$ & 35 & 18 & 12 & 33 & 98 \\
\hline $\mathrm{t}$ & Brand $B$ & 71 & $32(16)$ & 12 & 15 & 30 & 128 \\
\hline $\mathrm{h}$ & Brand $C$ & 32 & 20 & (08) & 05 & 16 & 73 \\
\hline $\mathrm{n}$ & Brand $D$ & 19 & 25 & 04 & (06) & 22 & 70 \\
\hline F & Brand $E$ & 18 & 12 & 05 & 03 & (12) & 38 \\
\hline $\begin{array}{l}\mathrm{r} \\
\mathrm{o}\end{array}$ & $\begin{array}{c}\text { Total } \\
\text { switches }\end{array}$ & 170 & 124 & 39 & 35 & 101 & 469 \\
\hline & $\begin{array}{c}\text { Post- } \\
\text { subscription }\end{array}$ & 180 & 140 & 47 & 41 & 113 & 521 \\
\hline
\end{tabular}

Brand $\mathrm{C}$ has attracted 18 subscribers from Brand A, 12 subscribers from Brand $\mathrm{B}, 04$ subscribers from Brand D and 05 subscribers from Brand E. While 08 subscribers remained with the current brand, 73 subscribers of Brand $\mathrm{C}$ have switched to other brands. The sample consists of 47 subscribers with the total of 39 switchers to Brand C compared to the 73 switchers from Brand C.

The sample consists of 41 Brand D subscribers. Compared to the 35 switchers to Brand D, it has reported that 70 subscribers of Brand D have switched to the other brands where only 06 subscribers have remained.

Brand $\mathrm{E}$ compared to Brand $\mathrm{C}$ and Brand $\mathrm{D}$ has attracted a higher number of subscribers from other brands. For instance, 33 Brand A subscribers, 30 Brand B subscribers, 16 Brand C subscribers and 22 Brand D subscribers have switched to Brand E. Accordingly, Brand E has attracted 101 subscribers altogether who enjoyed the other services previously. At the same time, while 12 subscribers remained, 38 subscribers of Brand $\mathrm{E}$ have switched to the other brands.

Further, it is fascinating to note that 469 mobile subscribers, out of 521 (for instance, $90 \%$ of the total sample) have switched among themselves. Meantime, total of 62 subscribers representing Brand A and Brand $\mathrm{B}$ have changed the package without changing the brand. 


\section{RESULTS AND DISCUSSION:}

The study was conducted to evaluate the nature of the behaviour of the millennial customers in terms of loyal versus switching intention in the context of the mobile phone services industry. The study revealed the factors affected the decisions between retention versus defection in accordance with their loyal versus switching behaviour. Accordingly, those key factors are presented in table 04 under the motives for retention versus the motives for defection including the number of subscribers who responded for each motive.

Table 04: Motives on Retention versus Defection

\begin{tabular}{|l|c|l|c|}
\hline \multicolumn{2}{|c|}{ Motives for Retention } & \multicolumn{2}{c|}{ Motives for Defection } \\
\hline $\begin{array}{l}\text { Lower rates of the existing service } \\
\text { operator }\end{array}$ & 32 & $\begin{array}{l}\text { Lower rates by competitive service } \\
\text { operators }\end{array}$ & 140 \\
\hline $\begin{array}{l}\text { Wide area network coverage of the } \\
\text { existing service operator }\end{array}$ & 28 & $\begin{array}{l}\text { Wide area network coverage by the } \\
\text { competitive service operators }\end{array}$ & 92 \\
\hline $\begin{array}{l}\text { Satisfaction with features and benefits } \\
\text { provided by existing service operator }\end{array}$ & $\begin{array}{l}\text { Dissatisfied with the service and } \\
\text { features provided by existing service } \\
\text { operator }\end{array}$ & 93 \\
\hline Switching barriers and switching costs & 14 & $\begin{array}{l}\text { Intention to enjoy new benefits, features } \\
\text { and packages }\end{array}$ & 88 \\
\hline $\begin{array}{l}\text { Heavy commitment and bond with the } \\
\text { existing brand and/or package }\end{array}$ & 26 & Influenced by peer groups & 32 \\
\hline
\end{tabular}

Referring to the motives on retention versus defection and the characteristics of types of customers as classified by various scholars, for instance as depicted in literature review table 01, eight types of customers were identified and categorized mainly under four types of stayers and four types of switchers. In selecting customers for each category, the most influential factor of each customer on the decision was considered. According to some respondents, a few such factors have affected their decision. For instance, it is well-known that many customers are price-sensitive. Accordingly, all of them can be considered as price-conscious customers. However, despite that logic, the respondents were requested to mention the most influential factor and evaluated their behaviour accordingly. Next, the behaviour of each customer was matched with the types of existing customers who have been introduced by various scholars as identified in the literature (Table 01). Moreover, the decision on customer retention by some mobile phone subscribers has also been determined by a few motives such as wide area coverage, satisfaction with packages and features of the service and low rates etc. Therefore, the most influential factor was considered in categorizing them as well.

Accordingly, 52 respondents were recognized as 'Brand Loyals' (Aaker, 1991; Rossiter \& Bellman, 2005) who love the brand as they enjoy the existing features and services including rates and network coverage of respective brand. The majority of 'Brand Loyal' category consists of Brand A subscribers while a few are represented by other brands. It is apparent that young consumers become brand loyal 
once they are satisfied with a good service (Chakraborty, 2019). Moreover, they expressed that they are hesitant to change their preferred brand due to the high level of brand loyalty exhibited. The next group was identified as 'Satisfied' customers who are predominantly satisfied with features and benefits provided by existing service providers (Aaker, 1991; Curasi \& Kennedy, 2002). They further mentioned that they have no compelling reason to change the existing service network. That particular category consists of 22 subscribers in the sample as shown in table 04. More importantly, a group of customers including 26 subscribers were identified and classified as 'Fanatics' based on their very high level of affection, emotional bond and loyalty to the preferred brand and the services (Brown, 1953; Aaker, 1991; Jones \& Sasser, 1995; Rowley, 2005; Moreira et al., 2016). This particular customer group is recognized as the most valuable and profitable customers by any business organization, thus treated them as a great asset. Accordingly, many organizations identify them as platinum customers (Zeithaml, Rust \& Lemon, 2001; Thakur \& Workman, 2016). The fanatic group of customers demonstrate the similar characteristics such as hard-core loyal (Brown, 1953), committed buyer (Aaker, 1991), committed loyal (Rowley, 2005) and platinum customer (Zeithaml et al., 2001). However, different terms are used by scholars to name this type of customer. Accordingly, this type of the customer is introduced as 'Fanatic' (person who is extremely enthusiastic about something: Oxford Dictionary) with a new term to the field of marketing based on their type and nature of the behaviour. It is fascinated to declare that those customers are extremely satisfied (delighted) with the benefits and services provided by respective service provider and exhibited a stronger bond to the brand and service packages. The 'Captive' (Aaker, 1991; Jones \& Sasser, 1995; Rowley, 2005) was identified as the fourth category of loyal customers who were resistant to change the existing brand and service package due to nonmonetary switching costs. Assessing switching costs has become one of the contemporary issues in evaluating customer behaviour (Keaveney, 1995; Jonathan et al., 2001; Eshghi et al., 2007; Deng et al., 2009; Chuang \& Tai, 2016; Jung et al., 2017) where switching costs are treated as "costs that are incurred by consumers for terminating transaction relationships and initiating a new relation" (Oyeniyi \& Abiodun, 2010; p: 112). Non-monetary switching costs have become severe barriers to switch a service provider in the current business context (Karunaratna, 2014; Karunaratna \& Kumara, 2018). As they expressed, they are afraid to change the mobile phone connection since it may cause to breach their relationships with colleagues, business partners and databases already maintained with the support of the existing mobile phone connection. According to Wei \& Lo (2006), mobile phone is a stronger tool today which strengthens the relationships or social bonds among family members, friends, and other interested parties. This group consists of 14 respondents in the sample. Mobile phone connection is considered as a long-term communication link between the service provider and the subscriber. Since each mobile phone subscriber tends to develop many relationships with various types of individuals and databases through his/her mobile phone connection, changing this connection may sometimes loose or breach those relationships and benefits. This type of behaviour is identified as a locking situation and 
the subscribers are bound by non-monetary switching costs (Patterson \& Smith, 2003; Kim, Park \& Jeong, 2004; Oyeniyi \& Abiodun, 2010).

As far as the switching motives were concerned, the respondents had mentioned different reasons that had affected their switching decisions. Among those, the four major factors were identified as pricesensitivity by 140 respondents, convenience as the means of wide area coverage and the service connection used my peers by 124 respondents, variety seeking which includes the intention of enjoying new benefits, features and packages by 88 respondents and dissatisfaction due to service failures and unfair charges by 93 respondents as presented in table 04. In analysing the type of behaviour in relation to the switching motives of respondents, four types of switchers, namely 'Convenience Seeker' (Rowley, 2005), 'Discontented Customer' (Jones \& Sasser, 1995), 'Variety Seeker' (Knox \& Walker, 2001) and 'Price-conscious Customer' (Lesser \& Hughes, 1986; Khojasteh \& Jadid, 2015) were identified in reference to the types of switcher categories as introduced by various scholars (Table 01 ).

Accordingly, the author presents a classification of customers who were recognized as the millennials who use the mobile phone services as shown in figure 01 with a definition of each type of customers. However, it could be noted that these types of customers would not be limited to the mobile phone services industry. Each market, irrespective of product or service, those types of customers can be recognized.

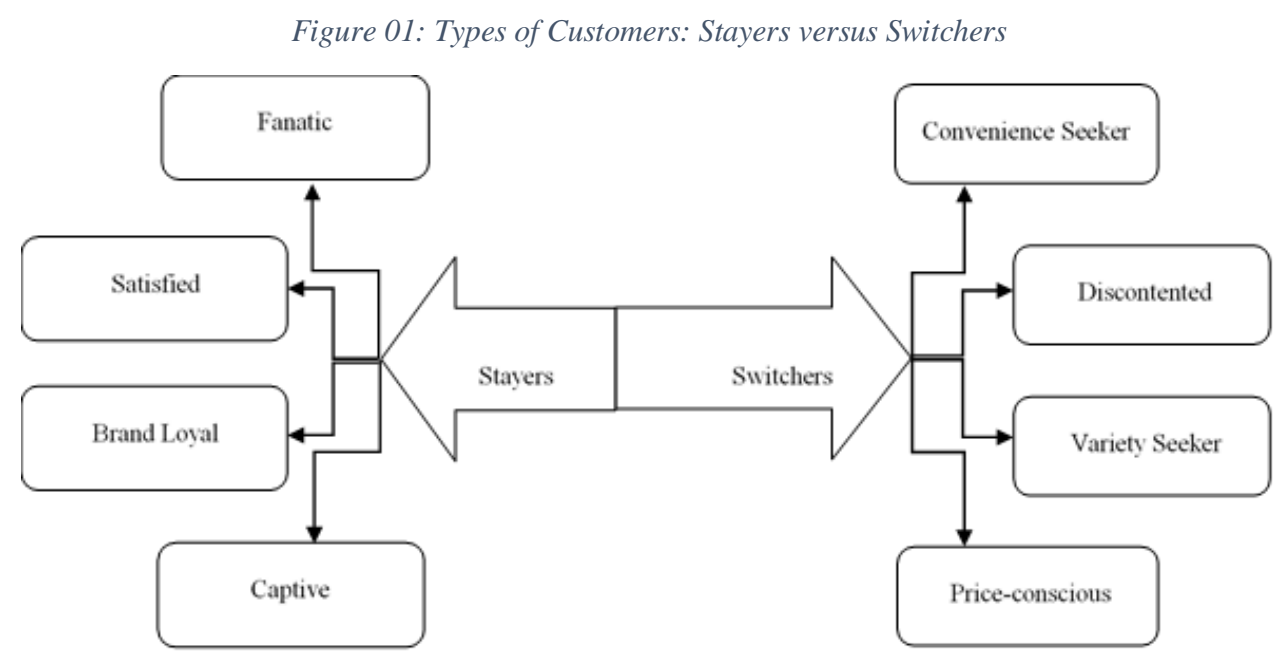

Data collection of the second stage of the study was driven for the purpose of developing the profile of each type of customer group identified in the first stage of the study. Accordingly, 168 respondents in representing 84 loyal customers and 84 switchers including 26 Fanatic, 22 Satisfied, 22 Brand loyal and 14 Captive and 21 from each four switching categories were selected from the total sample of 521 respondents as previously mentioned in the materials and methods section. Next, 08 separate focus group discussions were held with each group of customers and they were probed to reveal their 
perspectives in relation to their behaviour. Accordingly, each type of customer will be defined as follows.

Fanatic: The type of customer who is extremely committed to a brand, product, institution (company/firm), and/or any feature or element of a product, exhibits the highest level of loyalty. This type of customers would have the highest level of preference with what he/she consumes due to various need satisfying features and/or benefits. This type of customer is an important asset for an organization. They engage in positive word of mouth communication and play a key role as opinion leaders, recommending others to consume the product. Therefore, these customers are treated as the best source of attracting customers for a product, service or an organization.

Satisfied: The type of customer who exhibits a habitual buying behaviour can be recognized as reasonably satisfied customer. These customers enjoy the performance, features and benefits offered by the product. Due to the satisfactory performance and benefits those customers do not have any interest to search for alternatives. A customer who receives what he or she expected is most likely to be satisfied. Since the satisfaction is a requisite for loyalty, these customers remain loyal. Those customers talk favorably about the company and its offers, engage in positive word of mouth communication with their family member and colleagues, and repeat patronage.

Brand Loyal: This type of customer is essentially loyal to a particular brand. Those customers are strictly attached to a single or a few brands due to the highest level of quality, performance, reputation and/or uniqueness of the brand. Some customers attempt to represent their value and symbolize themselves through prestigious brands. This type of customers has keen interest on brand extensions and category extensions of their preferred brand.

Captive: The type of customer who is loyal to a brand, product, or institution (company/firm) due to high switching costs. Though these customers want to switch they are unable to behave in such a manner since they have to incur either monetary or non-monetary (time, energy, and psychological) switching costs. Therefore, they remain loyal. Sometimes, these customers remain loyal since they have lack of alternatives.

Convenience Seeker: This type of customer is usually service oriented and always seeks convenience. This type of customers is not loyal to a particular brand. They tend to switch wherever they could enjoy convenience. This type of customers may frequently shop at a particular store not because of loyalty but convenience of location or service efficiency. In the mobile phone services context, they have been driven to switch due to the inadequate service coverage of the existing service provider and motivated by peer groups who had been subscribed to competitive brands. 
Discontented Customer: This is a type of customer who is dissatisfied due to various reasons and unpleasant experiences. Customers become discontented when they perceive poor performance of the product, fewer benefits than expected, unfair and deceptive pricing practices etc. They engage in negative word of mouth communication and contribute to spoil the reputation of the product and the brand.

Variety Seeker: The type of customer who is not attached to any single brand, instead enjoys the benefits of different brands seeking the variety in the means of performance, experience, features, and/or benefits. Therefore, this type of customers does not exhibit preference for a specific brand, thus at the same time they have interest to try the competing brands easily shifting from one brand to another due to various advantages offered by the competing brands.

Price-conscious Customer: Price-sensitive Customer is essentially treated as a switcher and exhibits no loyalty to any particular brand at all. Moreover, they do not consider quality and performance of the product. Those customers always switch among different brands and products seeking the lower prices.

The focus-group discussions held with respondents were driven to identify the attitudinal and behavioural components of customer behaviour. The attitudinal and behavioural are two major components which are basically used by the academics and practitioners in measuring customer behaviour, especially the construct of customer loyalty (Dick \& Basu, 1994; Oliver, 1999; McMullan, 2005; Watson et al., 2015; Khajeheian \& Ebrahimi, 2020). For instance, Dick and Basu (1994) view customer loyalty as the strength of the relationship between an individual's relative attitude and repeat patronage. According to Chaudhuri and Holbrook (2001), behavioural loyalty which is also referred as purchase loyalty consists of repeated purchases of the brand, whereas attitudinal loyalty includes a degree of dispositional commitment in terms of some unique value association with the brand. Since there are conflicting theories in relation to the level of customer loyalty of the Millennials (Reisenwitz \& Iyer, 2009; Lodes \& Buff, 2009; Gurau, 2012), the analysis of this sort of behaviour was treated as one of the key objectives of the current study. Therefore, the attitudinal and behavioural components of each group were evaluated with a five point likert type scale ranging from 'very low' to 'very high'. The attitudinal component was measured using the scale items of intention of switching, intention of patronage and emotional bond whereas the behavioural component was measured using the scale items of enjoying the patronage, engage in positive word of mouth and brand recommendation. The respondents were advised to rate each item from very low to very high. Figure 02 depicts that fanatic and brand loyal customers exhibit a very high level of both attitudinal and behavioural loyalty while satisfied customers exhibit both at high. Behavioural loyalty of captives is high but attitudinal loyalty seems low. Discontented customers exhibit very low level of both attitudinal and behavioural loyalty. 
All three groups of variety seekers, convenience seekers and price-conscious customers illustrate low level of attitudinal and behavioural loyalty. It should be noted that these types of customers never declared the lack of loyalty or negative loyalty. They are not attached to a single brand since they are always seeking many benefits. Therefore, they become temporarily loyal to whatever brands where they enjoy the desired benefits.

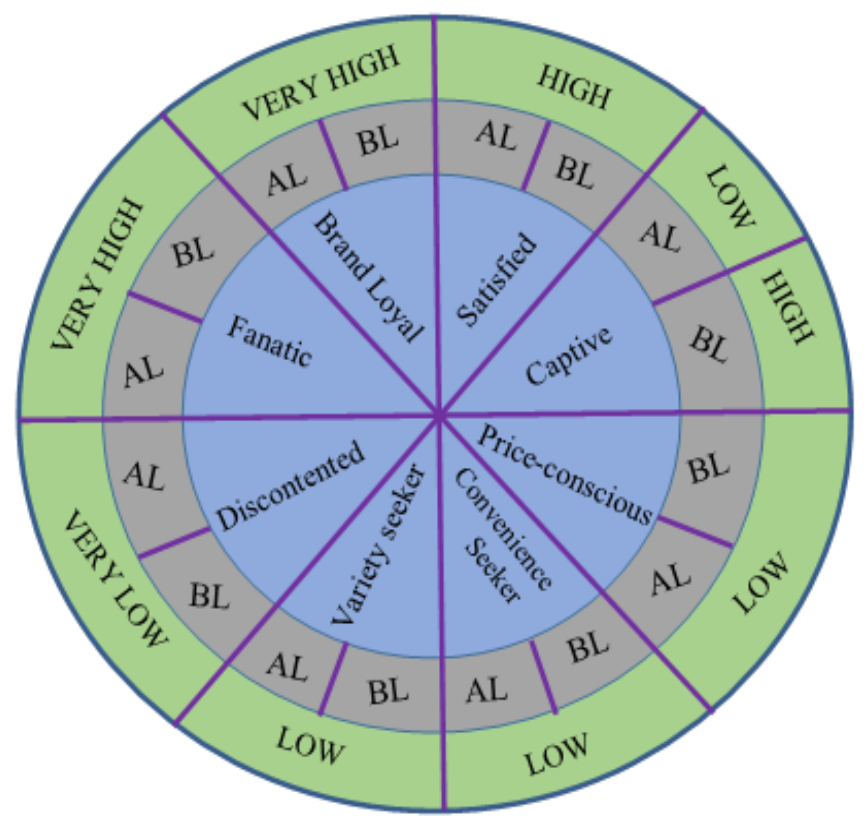

The model illustrated in figure 03 shows customer choice between retention and defection. In most of the cases, customers who exhibit high level of loyalty such as Hard-core Loyals (Brown, 1953), Committed Buyer (Aaker, 1991), Brand Loyals (Rossiter \& Bellman, 2005), Loyalists (Jones \& Sasser, 1995) or Loyals (Knox \& Walker, 2001) would tend to enjoy the benefits and attributes of the brand and retain with the existing brand in long run. Accordingly, the categories of fanatic, brand loyal and satisfied customers represent this nature of behaviour. However, in some cases for instance as illustrated by Jones and Sasser (1995), this retention would be due to high switching cost or monopolistic situation at the market. For instance, captive customers (Rowley, 2005) have such a behavioural pattern. Accordingly, the type of subscribers who were identified as captive customers in the current study represents this category. In these types of situations, even though customers' behavioural loyalty is high, their level of attitudinal loyalty would be lower. However, less loyal customers tend to switch to competitive brands seeking better quality, performance and fringe benefits. These types of customers would be either switchers (Brown, 1953; Aaker, 1991; Knox \& Walker, 2001) or butterflies (Reinartz \& Kumar, 2002) or Variety Seekers (Knox \& Walker, 2001). Price-conscious customers, discontented customers, convenience seekers and variety seekers in the current study have adopted this type of behaviour. 
Figure 03: Model of Customer Retention Vs Defection

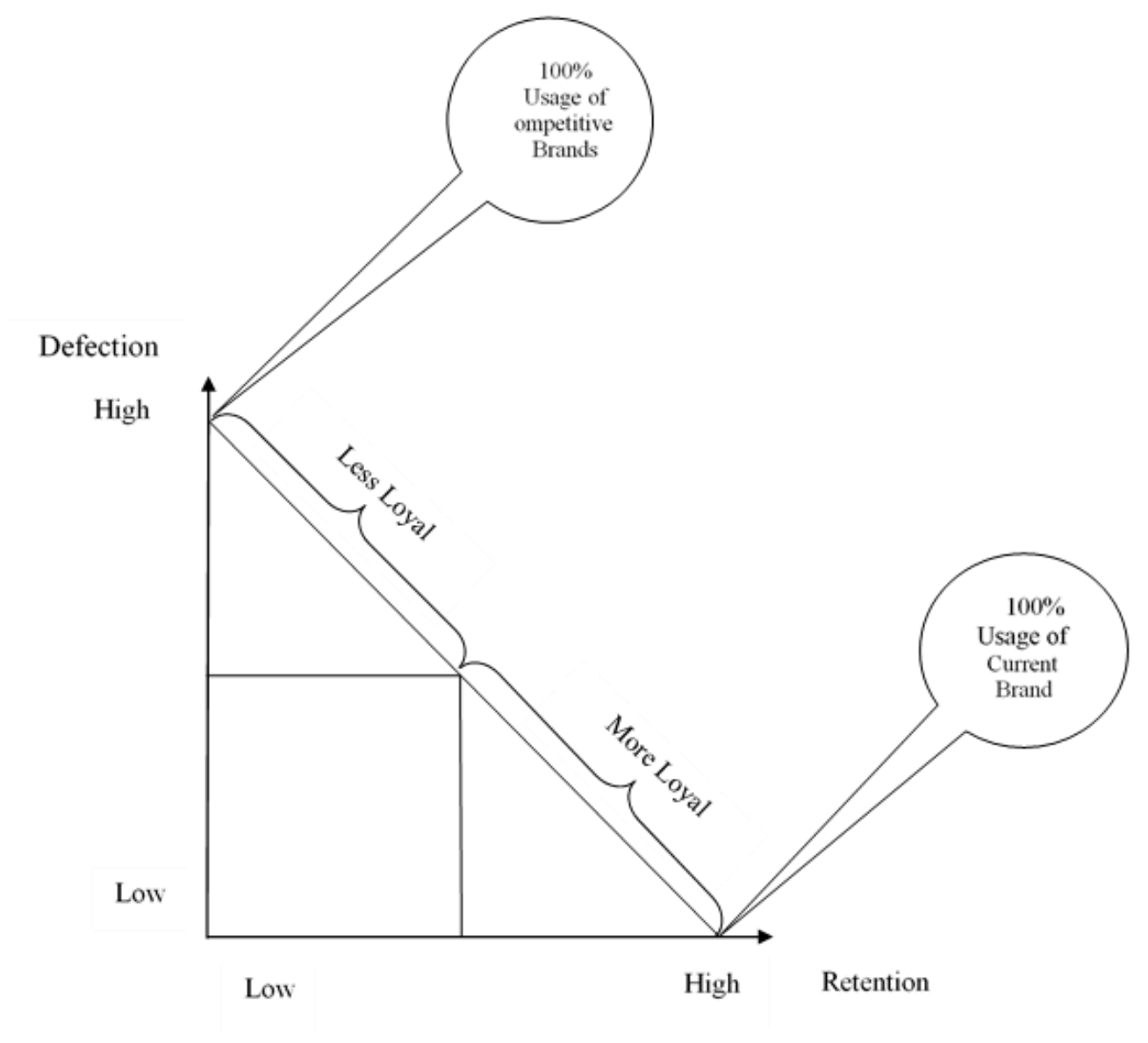

\section{CONCLUSIONS:}

This study which was conducted in two stages has twofold objectives. In the first step, it was examined the nature of the behaviour of the millennials in relation to the retention versus defection in the context of mobile phone services. The analysis of the first phase stimulated researcher to study the nature of behaviour of the respondents in depth. Since there are conflicting theories in relation to the level of customer loyalty of the Millennials, the nature of the behaviour of customers was evaluated with respect to switching and loyal behaviour. Further, the behaviour was appraised with reference to the attitudinal and behavioural components. The rigorous analysis of the study provides a substantial contribution to the behaviour of the Millennials. The findings of the study are decisive and provide both theoretical and practical implications. As theoretical implications, the study contributes a new classification of Millennial customers including four types of switching categories such as convenience seeker, discontented customer, variety seeker and price-conscious customer and four types of loyal categories such as fanatic, satisfied, brand loyal and captive in accordance to the different customer groups as introduced by various scholars. Although some of the customer groups have already been introduced by marketing scholars in different fields and contexts, the author attempted to identify them within the context of the Millennials as an unexplored phenomenon. Moreover, the findings of the study provide 
a direction to service providers and practitioners as practical implications in devising strategies for discouraging customer switching and enhancing the level of loyalty of existing customers and implementing customer retention strategies. It further coveys the message of importance in formulating different strategies according to the nature of behaviour among different groups of customers. As future research directions, the nature of each of these customer groups can be evaluated in other contexts since this study was conducted in the context of mobile phone services as enjoyed by the Millennials. For instance, the online behaviour of the Millennials including online education, online banking and online purchasing as well as social media engagement are such emerging themes which can be addressed. The undergraduates were employed as the respondents of the study. It may be considered as a limitation of the study. Therefore, different other groups who represent the millennial cohort can be targeted for future research studies as well.

\section{REFERENCES}

[1]. Aaker, D. A. (1991). Managing Brand Equity: Capitalizing on the value of a brand name. The Free Press, New York.

[2]. Ahn, J. H., Han, S. P., \& Lee, Y. S. (2006). Customer churn analysis: Churn determinants and mediation effects of partial defection in the Korean mobile telecommunications service industry. Telecommunications Policy, 30, 552-568.

[3]. Andreassen, W. T., \& Lanseng, E. (1997). The Principal's and agents' contribution to customer loyalty within an integrated services distribution channel. European Journal of Marketing, 31 (7), 487-503.

[4]. Andreassen, W. T., \& Lindestad, B. (1998). Customer loyalty and complex services: The impact of corporate image on quality, customer satisfaction and loyalty for customers with varying degrees of services expertise. International Journal of Services Industry Management, 9 (1), 7-23.

[5]. Ang, L., \& Buttle, F. (2006). Customer retention management processes: A quantitative study. European Journal of Marketing, 40 (1/2), 83-99.

[6]. Ascarza, E., Neslin, S. A., Netzer, O., Anderson, Z., Fader, P. S., Gupta, S., Hardie, B. G. S., Lemmens, A., Libai, B., Neal, D., Provost, F., \& Schrift, R. (2018). In Pursuit of Enhanced Customer Retention Management: Review, Key Issues, and Future Directions. Customer Needs and Solutions, 5 (1-2), 65-81.

[7]. Aydin, S., Ozer, G., \& Arasil, O. (2005). Customer loyalty and the effect of switching costs as a moderator variable: A case in the Turkish mobile phone market. Marketing Intelligence \& Planning, 23 (1), 89-103.

[8]. Bansal, H. S., \& Taylor, S. F. (1999). The Service Provider Switching Model (SPSM): A Model of Consumer Switching Behaviour in the Services Industry. Journal of Service Research, 2 (2), 200-218.

[9]. Bess, C. \& Bartolini, C. (2011). Cultivating Millennials and Harvesting the Value They Produce. Cutter IT Journal, 24 (9), 11-17. 
[10]. Bitner, M. J. (1990). Evaluating Service Encounters: The Effects of Physical Surroundings and Employee Responses. Journal of Marketing, 54 (2), 69-82.

[11]. Bowen, J. T., \& Shoemaker, S. (1998). Loyalty: A Strategic Commitment. CORNELL Hotel and Restaurant Administration Quarterly, 39 (1), 12-25.

[12]. Brown, G. H. (1953). Brand Loyalty: Fact or Fiction?. Advertising Age.

[13]. Burnham, T. A., Frels, J. K., \& Mahajan, V. (2003). Consumer Switching Costs: A Typology, Antecedents, and Consequences. Journal of the Academy of Marketing Science. 31 (2), 109-126.

[14]. Chakraborty, D. (2019). Factors responsible for making young urban consumers brand loyal: A study on mobile network operators. Journal of Management Development, 38 (7), 616-636.

[15]. Chaudhuri, A., \& Holbrook, M. B. (2001). The chain of effects from brand trust and brand affect to brand performance: The role of brand loyalty. Journal of Marketing, 65 (2), 81-93.

[16]. Chen, S. (2012). The customer satisfaction-loyalty relation in an interactive e-service setting: The mediators. Journal of Retailing and Consumer Services, 19 (2), 202-210.

[17]. Chuang, Y. F., \& Tai, Y. F. (2016). Research on customer switching behaviour in the service industry. Management Research Review, 39 (8), 925-939.

[18]. Crampton, S. M., \& Hodge, J. W. (2009). Generation Y: unchartered territory. Journal of Business \& Economics Research, 7 (4), 1-6.

[19]. Curasi, C. F., \& Kennedy, K. N. (2002). From prisoners to apostles: a typology of repeat buyers and loyal customers in service businesses. Journal of Services Marketing, 16 (4), 322-341.

[20]. Deng, Z., Zhang, J., Zhao, L., Lu, Y., \& Wei, K. K. (2009). Customer Satisfaction and Loyalty of Mobile Services. ICMB, Eighth International Conference on Mobile Business, 115-119.

[21]. Dick, A. S., \& Basu, K. (1994). Customer Loyalty: Toward an Integrated Conceptual Framework. Journal of the Academy of Marketing Science, 22 (2), 99-113.

[22]. Eastman, J. K., Rajesh Iyer, Liao-Troth, S., Williams, D. F., \& Griffin, M. (2014). The Role of Involvement on Millennials' Mobile Technology Behaviours: The Moderating Impact of Status Consumption, Innovation, and Opinion Leadership. Journal of Marketing Theory and Practice, 22 (4), 455470 .

[23]. Eshghi, A., Haughton, D., \& Topi, H. (2007). Determinants of customer loyalty in the wireless telecommunications industry. Telecommunications Policy, 31 (2), 93-106.

[24]. Ganesh, J., Arnold, M. J., \& Reynolds, K. E. (2000). Understanding the Customer Base of Service Providers: an Examination of the Differences between Switchers and Stayers. Journal of Marketing, 64 (3), 65-87.

[25]. Gul, R., Gul, R., Gul, F., \& Gul, N. (2018). Brand Resonance as a Driver of Customer Retention: Empirical Evidence from Microfinance Banks of Pakistan. Journal of Independent Studies \& Research: Management \& Social Sciences \& Economics, 16 (2), 35-48. 
[26]. Gurau, C. (2012). A Life-Stage Analysis of Consumer Loyalty Profile: Comparing Generation X and Millennial Consumers. Journal of Consumer Marketing, 29 (2), 103-113.

[27]. Han, H., Nguyen, H. N., Song, H., Chua, B., Lee, S., \& Kim, W. (2018). Drivers of brand loyalty in the chain coffee shop industry. International Journal of Hospitality Management, 72, 86-97.

[28]. Hahn, K., \& Kim, J. (2016). Understanding mobile phone case evaluative criteria of US Millennials. International Journal of Fashion Design, Technology and Education, 9 (1), 23-31.

[29]. Jonas-Dwyer, D., \& Pospisil, R. (2004). The millennial effect: Implications for academic development. Proceedings of the Annual International Conference of the Higher Education Research and Development Society of Australasia, 356-366.

[30]. Jonathan, L., Janghyuk, L., \& Lawrence, F. (2001). The impact of switching costs on the customer satisfaction-loyalty link: mobile phone service in France. Journal of Services Marketing, 15 (1), 35-48.

[31]. Jones, T. O., \& Sasser, W. E. (1995). Why Satisfied Customers Defect. Harvard Business Review, 73 (6), $88-99$.

[32]. Jung, J., Han, H., \& Oh, M. (2017). Travellers' switching behaviour in the airline industry from the perspective of the push-pull-mooring framework. Tourism Management, 59, 139-153.

[33]. Kandampully, J., \& Suhartanto, D. (2000). Customer loyalty in the hotel industry: the role of customer satisfaction and image. International Journal of Contemporary Hospitality Management, 12 (6), 346-351.

[34]. Karunaratna, A. C. (2014). An Examination of the Determinants of Customer Loyalty. Lambert Academic Publishing, Saarbrucken, Germany.

[35]. Karunaratna, A. C., \& Kumara, P. A. P. S. (2018). Determinants of customer loyalty: A literature review. Journal of Customer Behaviour, 17 (1-2), 49-73.

[36]. Kasiri, L. A., Cheng, K. T. G., Sambasivan, M., \& Sidin, S. (2017). Integration of standardization and customization: Impact on service quality, customer satisfaction, and loyalty. Journal of Retailing and Consumer Services, 35, 91-97.

[37]. Keaveney, S. M. (1995). Customer Switching Behaviour in Services Industries: An Exploratory Study. Journal of Marketing, 59 (2), 71-82.

[38]. Khajeheian, D., \& Ebrahimi, P. (2020). Media branding and value co-creation: effect of user participation in social media of newsmedia on attitudinal and behavioural loyalty. European Journal of International Management.

[39]. Khojasteh, M., \& Jadid, S. (2015). Decision-making framework for supplying electricity from distributed generation-owning retailers to price-sensitive customers. Utilities Policy, 37, 1-12.

[40]. Kim, M., Park, M., \& Jeong, D. (2004). The effects of customer satisfaction and switching barrier on customer loyalty in Korean mobile telecommunication services. Telecommunications Policy, 28 (2), 145159. 
[41]. Knox, S., \& Walker, D. (2001). Measuring and Managing Brand Loyalty. Journal of Strategic Marketing, 9 (2), 111-128.

[42]. Kotler, P., \& Keller, K. L. (2012), Marketing Management. Prentice-Hall, New Jersey, USA.

[43]. Lee, J., Lee, J., \& Feick, L. (2001). The impact of switching costs on the customer satisfaction-loyalty link: mobile phone services in France. Journal of Services Marketing, 15 (1), 35-48.

[44]. Lemmens, A., \& Gupta, S. (2020). Managing Churn to Maximize Profits. Marketing Science, Forthcoming.

[45]. Lemon, K. N., White, T. B., \& Winer, R. S., (2002). Dynamic Customer Relationship Management: Incorporating Future Considerations into the Service Retention Decision. Journal of Marketing, 66 (1), 1-14.

[46]. Lesser, J. A., \& Hughes, M. A. (1986). Towards a typology of shoppers. Business Horizons, 29 (6), 56-62.

[47]. Lodes, M., \& Buff, C. L. (2009). Are generation Y (Millennial) consumers brand loyal and is their buying behaviour affected in an economic recession? A preliminary study. Journal of Academy of Business and Economics, 9 (3), 127-134.

[48]. Machavolu, S. K., \& Narayana, M. S. (2016). Smart Millennials and their Changing Shopping Trends: A Case of Millennial Students in Nellore. International Journal for Modern Trends in Science and Technology, $2(8), 68-74$.

[49]. McMahon, M., \& Jung, J. H. (2011). The natives are restless: meeting the diversity and needs of millennial students in a large undergraduate unit. World Conference on Educational Multimedia, Hypermedia and Telecommunications, 476-481.

[50]. McMahon, M., \& Pospisil, R. (2005). Laptops for a digital lifestyle: Millennial students and wireless mobile technologies. Proceedings of the Australasian Society for Computers in Learning in Tertiary Education, 2, 421-431.

[51]. McMullan, R. (2005). A multiple-item scale for measuring customer loyalty development. Journal of Services Marketing, 19 (7), 470-481.

[52]. Mellens, M., Dekimpe, M. G., \& Steenkamp, J. B. E. M. (1996). A Review of Brand-Loyalty Measures in Marketing. Journal of Management and Economy, 41 (4), 507-533.

[53]. Moreira, A. C., Silva, P. M., \& Moutinho, V. F. (2016). Differences between stayers, switchers, and heavy switchers: A study in the telecommunications service market. Marketing Intelligence \& Planning, 34 (6), 843-862.

[54]. Norum, P. S. (2003). Examination of Generational Differences in Household Apparel Expenditures. Family and Consumer Sciences Research Journal, 32 (1), 52-75.

[55]. Nyadzayo, M. W, \& Khajehzadeh, S. (2016). The antecedents of customer loyalty: A moderated mediation model of customer relationship management quality and brand image. Journal of Retailing and Consumer Services, 30, 262-270.

[56]. Oliver, R. O. (1999). Whence Consumer Loyalty?. Journal of Marketing, 63 (special issue), 33-44. 
[57]. Oyeniyi, J. O., \& Abiodun, J. A. (2010). Switching Cost and Customers Loyalty in the Mobile Phone Market: The Nigerian Experience. Business Intelligence Journal, 3 (1), 111-121.

[58]. Patterson, P. G., \& Smith, T. (2003). A cross-cultural study of switching barriers and propensity to stay with services providers. Journal of Retailing, 79 (2), 107-120.

[59]. Peighambari, K. (2007), Developing and Testing a Model for Explaining Customer Retention Formation: Case of Iranian Mobile Telecommunication Services, Unpublished Master Thesis, Lulea University of Technology.

[60]. Pirc, M. (2006). Mobile Services and Phone as Consumption System-the Impact on Customer Switching. Proceedings of Helsinki Mobility Roundtable Sprouts: Working Papers on Information Systems, 6 (33).

[61]. Rai, A. K., \& Srivastava, M. (2012). Customer Loyalty Attributes: A Perspective. NMIMS Management Review, 22 (2), 49-76.

[62]. Raines, C. (2002). Managing Millennials. Connecting Generations: The Sourcebook, 16.

[63]. Reichheld, F. F. (2003). The One Number You Need to Grow. Harvard Business Review, 81 (12), $46-55$.

[64]. Reichheld, F. F. \& Kenny, D. W. (1990). The hidden advantages of customer retention. Journal of Retail Banking, 12 (4), 19-23.

[65]. Reichheld, F. F., Robert, Jr, G., \& Hopton, C. (2000). The loyalty effect - the relationship between loyalty and profits. European Business Journal, 12 (3), 134-139.

[66].

Reichheld, F. F., \& Schefter, P. (2000). E-Loyalty: Your Secret Weapon on the Web. Harvard Business Review, 78 (4), 105-113.

[67]. Reinartz, W., \& Kumar, V. (2002). The Mismanagement of Customer Loyalty. Harvard Business Review, 80 (7), 105-111.

[68]. Reisenwitz, T. H., \& Iyer, R. (2009). Differences in generation x and generation y: Implications for the organization and marketers. Marketing Management Journal, 19 (2), 91-103.

[69]. Richards, J. (2011). Tips for Teaching Millennial Students in your Higher Ed Class. National Technology and Social Science Conference, 46 (2), 209-215.

[70]. Rossiter, J. R., \& Bellman, S. (2005). Marketing communications; theory and applications. Prentice-Hall, Frenchs Forest NSW, Australia.

[71]. Rowley, J. (2005). The four Cs of customer loyalty. Marketing Intelligence \& Planning, 23 (6), 574-581.

[72]. Russell-Bennett, R., McColl-Kennedy, J. R., \& Coote, L. V. (2007). Involvement, satisfaction and brand loyalty in a small business services setting. Journal of Business Research, 60 (12), 1253-1260.

[73]. Sandelowski, M. (2000). Whatever Happened to Qualitative Description?. Research in Nursing \& Health, $23,334-340$.

[74]. Schiffman, L. G, Wisenblit, J., \& Kumar, S. R. (2015). Consumer Behaviour. Prentice Hall, New Delhi. 
[75]. Seo, D., Ranganathan, C., \& Babad, Y. (2008). Two-level model of customer retention in the US mobile telecommunications service market. Telecommunications Policy, 32, 182-196.

[76]. Shaaban, E., \& Hassanien, A. E. (2016). Churn Prediction Retention Framework. International Journal of Advanced in Computer Science \& Its Applications, 6 (1), 11-16.

[77]. Singh, J., \& Sirdeshmukh, D. (2000). Agency and Trust Mechanisms in Consumer Satisfaction and Loyalty Judgements. Journal of the Academy of Marketing Science, 28 (1), 150-167.

[78]. Skogland, I., \& Siguaw, J. A. (2004). Are Your Satisfied Customers Loyal?. Cornell Hotel and Restaurant Administration Quarterly, 45 (3), 221-234.

[79]. Thakur, R., \& Workman, L. (2016). Customer portfolio management (CPM) for improved customer relationship management (CRM): Are your customers platinum, gold, silver, or bronze?. Journal of Business Research, 69 (10), 4095-4102.

[80]. Voon, B. H. (2017). Service Environment of Restaurants: Findings from the youth customers. Journal of ASIAN Behavioural Studies, 2 (2), 67-77.

[81]. Vuuren, T. V., Roberts-Lombard, M., \& Tonder E. V. (2012). Customer satisfaction, trust and commitment as predictors of customer loyalty within an optometric practice environment. South African Business Review, $16(3), 81-96$.

[82]. Vyas, V., \& Raitani, S. (2014). Drivers of customers' switching behaviour in Indian banking industry. International Journal of Bank Marketing, 32 (4), 321-342.

[83]. Watson, G. F., Beck, J. T., Henderson, C. M., \& Palmatier, R. W. (2015). Building, measuring, and profiting from customer loyalty. Journal of the Academy of Marketing Science, 43 (6), 790-825.

[84]. Wei, R., \& Lo, V. H. (2006). Staying connected while on the move: Cell phone use and social connectedness. New Media \& Society, 8 (1), 53-72.

[85]. Wieringa, J. E., \& Verhoef, P. C. (2007). Understanding Customer Switching Behaviour in Liberalizing Service Market: An Exploratory Study. Journal of Service Research, 10 (2), 174-186.

[86]. Yi, Y., \& Jeon, H. (2003). Effects of Loyalty Programs on Value Perception, Program Loyalty, and Brand Loyalty. Journal of the Academy of Marketing Science, 31 (3), 229-240.

[87]. Young, A. M., \& Hinesly, M. D. (2012). Identifying Millennials' key influencers from early childhood: insights into current consumer preferences. Journal of Consumer Marketing, 29 (2), 146-155.

[88]. Zeithaml, V. A., Berry, L. L., \& Parasuraman, A. (1996). The Behavioural Consequences of Services Quality. Journal of Marketing, 60 (2), 31-46.

[89]. Zeithaml, V. A., Rust, R. T., \& Lemon, K. N. (2001). The Customer Pyramid: Creating and Serving Profitable Customers. California Management Review, 43 (4), 118-142. 